\title{
Lymphocyte subset alterations with disease severity, imaging manifestation, and delayed hospitalization in COVID-19 patients
}

Daxian $\mathrm{Wu}^{1+}$, Xiaoping $\mathrm{Wu}^{1 \dagger}$, Jiansheng Huang ${ }^{1}$, Qunfang Rao', Qi Zhang ${ }^{2}$ and Wenfeng Zhang ${ }^{1 *}$ (D)

\begin{abstract}
Background: COVID-19 continuously threated public health heavily. Present study aimed to investigate the lymphocyte subset alterations with disease severity, imaging manifestation, and delayed hospitalization in COVID-19 patients.

Methods: Lymphocyte subsets was classified using flow cytometry with peripheral blood collected from 106 patients.

Results: Multivariate logistic regression showed that chest tightness, lymphocyte count, and Y-glutamyl transpeptidase were the independent predictors for severe COVID-19. The T cell, CD4 ${ }^{+} \mathrm{T}$ cell and B cell counts in severe patients were significantly lower than that in mild patients ( $p=0.004,0.003$ and 0.046 , respectively). Only the $T$ cell count was gradually decreased with the increase of infiltrated quadrants of lesions in computed tomography (CT) $(p=0.043)$. The T cell, CD4 ${ }^{+} \mathrm{T}$ cell, and $\mathrm{CD} 8^{+} \mathrm{T}$ cell counts were gradually decreased with the increase of infiltrated area of the maximum lesion in $C T(p=0.002,0.003,0.028$; respectively). For severe patients, the counts of T cell, CD4 ${ }^{+} T$ cell, CD8 ${ }^{+} T$ cell gradually decreased with the increased delayed hospitalization $(p=0.001,0.03$, and $<0.001$, respectively). The proportions of $\mathrm{T}$ cell, $C D 8^{+} \mathrm{T}$ cell gradually decreased with the increased delayed hospitalization (both $p<0.001$ ), but the proportions of NK cell, B cell gradually increased with the increased delayed hospitalization ( $p=0.007$, and 0.002 , respectively). For mild patients, only the NK cell count was gradually decreased with the increased delayed hospitalization $(p=0.012)$.
\end{abstract}

Conclusion: T lymphocyte and its subset negatively correlated with disease severity, CT manifestation and delayed hospitalization. The counts of lymphocyte subset were changed more profound than their proportions.

Keywords: COVID-19, Delayed hospitalization, Computed tomography, Lymphocyte subsets, Flow cytometry

\footnotetext{
* Correspondence: wenfengzhang0000@163.com

${ }^{\dagger}$ Daxian Wu and Xiaoping Wu contributed equally to this work.

'Department of Infectious Diseases, the First Affiliated Hospital, Nanchang

University, No.17 Yongwai Street, Donghu District, Nanchang 330006, Jiangxi

Province, China

Full list of author information is available at the end of the article
}

(C) The Author(s). 2021 Open Access This article is licensed under a Creative Commons Attribution 4.0 International License, which permits use, sharing, adaptation, distribution and reproduction in any medium or format, as long as you give appropriate credit to the original author(s) and the source, provide a link to the Creative Commons licence, and indicate if changes were made. The images or other third party material in this article are included in the article's Creative Commons licence, unless indicated otherwise in a credit line to the material. If material is not included in the article's Creative Commons licence and your intended use is not permitted by statutory regulation or exceeds the permitted use, you will need to obtain permission directly from the copyright holder. To view a copy of this licence, visit http://creativecommons.org/licenses/by/4.0/. The Creative Commons Public Domain Dedication waiver (http://creativecommons.org/publicdomain/zero/1.0/) applies to the data made available in this article, unless otherwise stated in a credit line to the data. 


\section{Introduction}

Coronavirus disease 2019 (COVID-19) is a newly emerged viral infection caused by the severe acute respiratory syndrome coronavirus 2 (SARS-CoV-2) [1]. COVID-19 is highly contagious and has become pandemic quickly. Innate and adaptive immune responses are activated in COVID-19 patients, perhaps uncontrolled innate and adaptive immune responses may lead to locally and systemically tissue damage. Recently, the alterations of lymphocyte subsets in COVID-19 patients had attracted the attention of researchers for exhausted lymphocytes were a feature of severe COVID-19 [2-4]. An overall decline of lymphocyte subsets including $\mathrm{CD}^{+} \mathrm{T}$ cells, $\mathrm{CD}^{+} \mathrm{T}$ cells, $\mathrm{B}$ cells, and NK cells has been reported in severe and deceased COVID-19 patients $[5,6]$. However, vary patterns of lymphocyte subsets abnormality in severe COVID-19 patients also have been demonstrated by other studies [7-10]. Reports involving the change of $\mathrm{CD}^{+}$to $\mathrm{CD}^{+} \mathrm{T}$ cells ratio were also inconsistent $[9,11,12]$. Thus, the reported patterns of lymphocyte subsets in patients with COVID-19 were diverse and controversial, and necessitated to clear more.

Lung computed tomography (CT) plays an important role in the early diagnosis and evaluating the disease severity of COVID-19 for different imaging manifestations are demonstrated at different stages of the disease [13]. At the early stages of the COVID-19, unilateral or bilateral ground-glass opacity (GGO) is most common in the posterior aspects and periphery of the lungs. With the progression of the disease, the scope and number of GGO are gradually expanding and fusion. At the later stages of the COVID-19, crazy paving appearance and pulmonary consolidation begin to appear and are gradually extensive. As far, the correlation of lymphocyte subsets with the lesion manifestation in lung CT was not be well documented and necessitated to clarify.

Here, we first investigated alterations of lymphocyte subsets in severe COVID-19 patients. Then, we observed the correlations of lymphocyte subsets with the number, quadrant, and area of lesions in lung CT. Finally, we investigated the impacts of the lymphocyte subsets in patients with delayed hospitalization.

\section{Method}

\section{Patients}

One hundred and six COVID-19 patients who were confirmed by positive RNA of SARS-CoV-2 using throat swab specimens were prospectively recruited from June 23, 2020 to February 29, 2020 at the First Affiliated Hospital, Nanchang University. Patients were stratified at their admission, 33 patients with severe COVID-19 was diagnosed according the guideline of the American
Thoracic Society and Infectious Diseases Society of America [14]. 73 cases not meeting the criteria were classified as mild COVID-19. All procedures followed were in accordance with the Ethics Committees of the First Affiliated Hospital, Nanchang University, and with the Helsinki Declaration of 1975, as revised in 2000. All patients enrolled in study were over 16 years old, and written informed consent was obtained from themselves or their legal representatives.

\section{Data acquisition}

Data on the demography, epidemiology, symptoms and signs, laboratory tests, as well as radiography findings were extracted from electronic medical records using a predesigned datasheet. All laboratory tests were conducted in the Central Clinical Laboratory of the First Affiliated Hospital, Nanchang University and were adopted if they were performed with fasting blood samples at patients' admission.

\section{Flow cytometry}

Anticoagulated peripheral blood samples with EDTA were collected from COVID-19 patients at their admission and tested within $6 \mathrm{~h}$. Lymphocyte subsets was performed by Cytomics FC 500 flow cytometer and analysed by CXP Analysis software (Beckman Coulter, Brea, California). Anti-CD3 was conjugated by PE-texas red (ECD), anti-CD4, anti-CD8, anti-CD19 were conjugated by fluorescein isothiocyanate (FITC), PE-Cy5 (PC5), and R-phycoerythrin (PE) respectively. The count of NK cell marked by $\mathrm{CD} 3^{-} \mathrm{CD} 16^{+} \mathrm{CD}^{2} 6^{+}$was auto calculated CXP Analysis software. All tests were performed according to the manufacturer's instructions.

\section{Statistics}

Statistical analysis was performed with SPSS 25.0 (SPSS, Inc., Chicago, USA) and MedCalc (MedCalc Software Ltd., Ostend, Belgium). Continuous data were expressed as the mean \pm standard deviations or medians with quartile (P25-P75) and categorical data were expressed as numbers (\%). The Student's t-test was used for continuous data distributed normally, and the Mann-Whitney $\mathrm{U}$ test was used for continuous data distributed abnormally. The $\chi^{2}$ or Fisher's tests were used for categorical data. Rank correlation was analysed using the Spearman method. A $p$ values of less than 0.05 was considered statistically significant. Independent risk factors were identified using multivariate logistic regression according to the forward Wald method, with entry and removal probabilities of 0.05 and 0.10 , respectively. 


\section{Results}

Baseline clinical characteristics of patients with COVID-19 The age of patients with COVID-19 was $46.17 \pm 14.39$, and $60.4 \%$ patients were male. The mean of the time from onset to hospitalization ( $\mathrm{TOH})$ was 5 days. Among the 106 COVID-19 patients, $83(78.3 \%)$ patients had a clear exposure history, and $33(31.1 \%)$ patients had one or more comorbidities. The most frequent comorbidity was bacterial infection (11.3\%), followed by diabetes (9.4\%) and hypertension (7.5\%). As expected, fever (91.5\%), dry cough (43.4\%), and chest tightness $(32.1 \%)$ were the top three frequent symptoms. Chills (20.8\%), fatigue $(19.8 \%)$, and sore throat (18.9\%) were also common, but rhinorrhea or rhinobyon (5.7\%), diarrhea (6.6\%), and myalgia (7.5\%) were relatively rare in COVID-19 patients (Table 1).

\section{Independent indictors for severe COVID-19}

As shown in Table 1, univariate logistic regression indicated that the $\mathrm{TOH}$ of severe patients was significantly longer than of mild patients [7 (4-10) vs. $4(2-7)$ days; $p=0.011$ ]. The frequency of comorbidities in severe patients was higher than mild patients ( $45.5 \%$ vs. $24.7 \%$; $p=0.035)$. The frequency of sputum production, chest tightness, or polypnea was higher in severe patients than mild patients (all $p<0.05$ ). The level of C-reactive protein, as well as levels of direct bilirubin, $\gamma$-glutamyl transpeptidase, lactate dehydrogenase, and D-dimer were significantly higher in severe patients than mild patients (all $\mathrm{p}<0.05$ ). However, the levels of lymphocyte count and albumin were significantly lower in severe cases compared to mild cases. Multivariate logistic regression showed that chest tightness, lymphocyte count, and $\gamma$-glutamyl transpeptidase were the independent indictors to predict severe COVID-19.

\section{Lymphocyte subsets in severe COVID-19 patients}

Giving the lymphocyte count was an important indicator to predict severe COVID-19, we further investigated the alteration of lymphocyte subsets in patients with severe COVID-19. As shown in Fig. 1A, the T cell count in severe patients was significantly lower than that in mild patients [487.00 (291.50, 819.50) vs. $766.00(525.50,1036.50) / \mu \mathrm{L}$; $p=0.004]$. The $\mathrm{CD}^{+} \mathrm{T}$ cell and B cell counts in severe patients were also significantly lower than that in mild patients $[272.00(177.00,497.50)$ vs. 455.00 (283.50, 612.50) and $92.00(57.50,160.00)$ vs. $136.00(82.50,213.00) / \mu \mathrm{L} ; p=$ 0.003 and 0.046 , respectively]. There is no significant difference for $\mathrm{CD}^{+} \mathrm{T}$ cell or NK cell count between severe and mild patients. The difference of $\mathrm{CD}^{+}$to $\mathrm{CD}^{+}$ratio between severe and mild patients was not significant. No significant difference for proportion of lymphocyte subset was observed between severe and mild patients (Fig. 1B).

\section{The basic lymphocyte status of patients with comorbidities}

As described above, patients with comorbidities were prone to severe COVID-19, and the decreased $\mathrm{T}$ cell, $\mathrm{CD}^{+}{ }^{+} \mathrm{T}$ cell and $\mathrm{B}$ cell counts were closed related to severe COVID-19. Thus, we further investigated that whether the patients with comorbidities were prone to severe COVID-19 related to their basic lymphocyte status? As shown in Fig. 2, there are no significant differences between COVID-19 patients with comorbidity and who without comorbidity, no matter for the counts or the proportions of all lymphocyte subsets (Fig. 2A-B). The same result was obtained when the COVID-19 patients were stratified with disease severity (Fig. 2C-F). Those results suggested that the reason why patients with comorbidities were prone to severe COVID-19 were independent of their basic lymphocyte status.

\section{Lymphocyte subsets alterations with CT manifestation}

In order to assess the manifestation of lesions in lung CT, present study simply scored the number, quadrant, and area of lesions. For the number of lesions, patients were classified to 3 subgroups named patients with no lesion, $\leq 3$ lesions, and $>3$ lesions. For the quadrant of lesions, patients were classified to 3 subgroups, that is, patients with no quadrant, $\leq 3$ quadrants, and $>3$ quadrants. For the area of the maximum lesion, patients were classified no infiltration when there is no lesion in CT. patients with minor and major infiltration were classified when the area of the maximum lesion were $\leq 100$ $\mathrm{cm}^{2}$ and $>100 \mathrm{~cm}^{2}$ respectively. As shown in Fig. 3A-C, the lymphocyte counts were gradually decreased with the increased number, quadrant, or area of lesions ( $p=$ $0.002,0.002$, and $<0.001$ respectively). No significant trend of absolute count of any lymphocyte subset was observed with the increase of lesion number (Fig. 4A). Only the $\mathrm{T}$ cell count was gradually decreased with the increase of infiltrated quadrants $(p=0.043)$ (Fig. 4B). The $\mathrm{T}$ cell, $\mathrm{CD} 4^{+} \mathrm{T}$ cell, and $\mathrm{CD}^{+} \mathrm{T}$ cell counts were gradually decreased with the increase of infiltrated area ( $p=0.002,0.003,0.028$, respectively) (Fig. 4C). However, the trend of $\mathrm{CD}^{+}$to $\mathrm{CD}^{+}$ratio was not significant no matter with the increase of the number, quadrant, or the area of lesions. For proportion, there is also no significant trend of any lymphocyte subset with aggravated CT manifestation (Fig. 4D-F).

\section{Lymphocyte subsets alterations with $\mathrm{TOH}$}

The lymphocyte counts were gradually decreased with the increased $\mathrm{TOH}(p<0.001$, Fig. 3D). Lymphocyte subsets analysis showed that the $\mathrm{T}$ cell count, as well as $\mathrm{CD}^{+} \mathrm{T}$ cell, and $\mathrm{CD}^{+} \mathrm{T}$ cell counts were gradually decreased with the increased $\mathrm{TOH}(p=0.003,0.002$, and 0.013 , respectively). The NK cell count was also 
Table 1 Characteristics at admission of the patients with COVID-19

\begin{tabular}{|c|c|c|c|c|c|c|c|}
\hline \multirow[t]{2}{*}{ Variable } & \multirow[t]{2}{*}{ Total $(n=106)$} & \multirow[t]{2}{*}{ Mild $(n=73)$} & \multirow[t]{2}{*}{ Severe $(n=33)$} & \multicolumn{2}{|c|}{$\begin{array}{l}\text { Univariate logistic } \\
\text { regression }\end{array}$} & \multicolumn{2}{|c|}{$\begin{array}{l}\text { Multivariate logistic } \\
\text { regression }\end{array}$} \\
\hline & & & & $\mathrm{HR}(95 \% \mathrm{Cl})$ & $P$ & HR $(95 \% \mathrm{Cl})$ & $\mathbf{P}$ \\
\hline \multicolumn{8}{|c|}{ Epidemiological and clinical characteristics } \\
\hline Age (years) & $46.17 \pm 14.39$ & $44.95 \pm 13.59$ & $48.88 \pm 15.88$ & $\begin{array}{l}1.020(0.990- \\
1.050)\end{array}$ & 0.194 & & \\
\hline Gender (female/male) & $42 / 64$ & $31 / 42$ & $11 / 22$ & $\begin{array}{l}1.476(0.625- \\
3.488)\end{array}$ & 0.375 & & \\
\hline $\begin{array}{l}\text { Time from onset to } \\
\text { hospitalization (d) }\end{array}$ & $5(2-8)$ & $4(2-7)$ & $7(4-10)$ & $\begin{array}{l}1.156(1.034- \\
1.293)\end{array}$ & 0.011 & & \\
\hline Exposure history $(\mathrm{Y} / \mathrm{N})$ & $83(78.3 \%)$ & $55(75.3 \%)$ & $28(84.8 \%)$ & $\begin{array}{l}1.833(0.616- \\
5.453)\end{array}$ & 0.276 & & \\
\hline Any comorbidities & $33(31.1 \%)$ & $18(24.7 \%)$ & $15(45.5 \%)$ & $\begin{array}{l}2.546(1.069- \\
6.063)\end{array}$ & 0.035 & & \\
\hline Hypertension & $8(7.5 \%)$ & $4(5.5 \%)$ & $4(12.1 \%)$ & $\begin{array}{l}2.379(0.557- \\
10.166)\end{array}$ & 0.242 & & \\
\hline Diabetes & $10(9.4 \%)$ & $6(8.2 \%)$ & $4(12.1 \%)$ & $\begin{array}{l}1.540(0.404- \\
5.871)\end{array}$ & 0.527 & & \\
\hline Hepatitis B & $7(6.6 \%)$ & $6(8.2 \%)$ & $1(30 \%)$ & $\begin{array}{l}0.349(0.040- \\
3.021)\end{array}$ & 0.339 & & \\
\hline Bacterial infection & $12(11.3 \%)$ & $7(9.6 \%)$ & $5(15.2 \%)$ & $\begin{array}{l}1.684(0.492- \\
5.759)\end{array}$ & 0.406 & & \\
\hline \multicolumn{8}{|l|}{ Signs and symptoms } \\
\hline Fever & $97(91.5 \%)$ & $66(90.4 \%)$ & $31(93.9 \%)$ & $\begin{array}{l}1.644(0.323- \\
8.377)\end{array}$ & 0.550 & & \\
\hline Dry cough & $46(43.4 \%)$ & $30(41.1 \%)$ & $16(48.5 \%)$ & $\begin{array}{l}1.349(0.590- \\
3.084)\end{array}$ & 0.478 & & \\
\hline Sputum production & $12(11.3 \%)$ & $5(6.8 \%)$ & $7(21.2 \%)$ & $\begin{array}{l}3.662(1.067- \\
12.570)\end{array}$ & 0.039 & & \\
\hline Chills & $22(20.8 \%)$ & 17 (23.3\%) & $5(15.2 \%)$ & $\begin{array}{l}0.588(0.197- \\
1.759)\end{array}$ & 0.342 & & \\
\hline Myalgia & $8(7.5 \%)$ & $6(8.2 \%)$ & $2(6.1 \%)$ & $\begin{array}{l}0.720(0.138- \\
3.774)\end{array}$ & 0.698 & & \\
\hline Chest tightness & $34(32.1 \%)$ & $15(20.5 \%)$ & $19(57.6 \%)$ & $\begin{array}{l}5.248(2.147- \\
12.827)\end{array}$ & $\begin{array}{l}< \\
0.001\end{array}$ & $\begin{array}{l}3.256(1.134- \\
9.345)\end{array}$ & 0.028 \\
\hline Polypnea & $14(13.2 \%)$ & $4(5.5 \%)$ & $10(30.3 \%)$ & $\begin{array}{l}7.500(2.145- \\
26.227)\end{array}$ & 0.002 & & \\
\hline Fatigue & $21(19.8 \%)$ & $12(16.4 \%)$ & $9(27.3 \%)$ & $\begin{array}{l}1.906(0.712- \\
5.104)\end{array}$ & 0.199 & & \\
\hline Headache/ dizziness & $13(12.3 \%)$ & $12(16.4 \%)$ & $1(3.0 \%)$ & $\begin{array}{l}0.159(0.020- \\
1.277)\end{array}$ & 0.084 & & \\
\hline Sore throat & $20(18.9 \%)$ & $14(19.2 \%)$ & $6(18.2 \%)$ & $\begin{array}{l}0.937(0.325- \\
2.701)\end{array}$ & 0.903 & & \\
\hline Rhinorrhea/ Rhinobyon & $6(5.7 \%)$ & $5(6.8 \%)$ & $1(3.0 \%)$ & $\begin{array}{l}0.425(0.048- \\
3.789)\end{array}$ & 0.443 & & \\
\hline Diarrhea & $7(6.6 \%)$ & $4(5.5 \%)$ & $3(9.1 \%)$ & $\begin{array}{l}1.725(0.364- \\
8.185)\end{array}$ & 0.493 & & \\
\hline \multicolumn{8}{|l|}{ Laboratory parameters } \\
\hline CRP (mg/L) & $12.63(3.53-40.49)$ & $9.00(2.46-24.93)$ & $22.99(6.36-77.01)$ & $\begin{array}{l}1.011(1.002- \\
1.021)\end{array}$ & 0.018 & & \\
\hline WBC $\left(\times 10^{9} / \mathrm{L}\right)$ & $5.14(3.63-6.79)$ & $4.84(3.60-6.63)$ & $5.68(3.68-7.00)$ & $\begin{array}{l}1.076(0.926- \\
1.249)\end{array}$ & 0.339 & & \\
\hline Lymphocyte count $\left(\times 10^{9} / \mathrm{L}\right)$ & $0.99(0.65-1.40)$ & $1.13(0.86-1.58)$ & $0.68(0.40-0.99)$ & $\begin{array}{l}0.065(0.018- \\
0.244)\end{array}$ & $\begin{array}{l}< \\
0.001\end{array}$ & $\begin{array}{l}0.097(0.024- \\
0.396)\end{array}$ & 0.010 \\
\hline
\end{tabular}


Table 1 Characteristics at admission of the patients with COVID-19 (Continued)

\begin{tabular}{|c|c|c|c|c|c|c|c|}
\hline \multirow[t]{2}{*}{ Variable } & \multirow[t]{2}{*}{ Total $(n=106)$} & \multirow[t]{2}{*}{ Mild $(n=73)$} & \multirow[t]{2}{*}{ Severe $(n=33)$} & \multicolumn{2}{|c|}{$\begin{array}{l}\text { Univariate logistic } \\
\text { regression }\end{array}$} & \multicolumn{2}{|c|}{$\begin{array}{l}\text { Multivariate logistic } \\
\text { regression }\end{array}$} \\
\hline & & & & HR $(95 \% \mathrm{Cl})$ & $P$ & HR $(95 \% \mathrm{Cl})$ & $\mathbf{P}$ \\
\hline Neutrophils count $\left(\times 10^{9} / \mathrm{L}\right)$ & $3.47(2.30-5.17)$ & $3.19(2.07-4.89)$ & $3.95(2.66-5.95)$ & $\begin{array}{l}1.163(0.996- \\
1.357)\end{array}$ & 0.055 & & \\
\hline $\mathrm{RBC}\left(\times 10^{12} / \mathrm{L}\right)$ & $4.61 \pm 0.55$ & $4.66 \pm 0.54$ & $4.50 \pm 0.57$ & $\begin{array}{l}0.571(0.262- \\
1.241)\end{array}$ & 0.157 & & \\
\hline Hemoglobin (g/L) & $143.59 \pm 16.91$ & $144.29 \pm 17.37$ & $142.06 \pm 16.02$ & $\begin{array}{l}0.992(0.969- \\
1.016)\end{array}$ & 0.530 & & \\
\hline Platelets $\left(\times 10^{9} / \mathrm{L}\right)$ & $176.16 \pm 62.11$ & $181.53 \pm 61.09$ & $164.27 \pm 63.65$ & $\begin{array}{l}0.995(0.987- \\
1.003)\end{array}$ & 0.189 & & \\
\hline Albumin (g/L) & $43.03 \pm 6.07$ & $44.32 \pm 5.71$ & $40.16 \pm 5.94$ & $\begin{array}{l}0.857(0.781- \\
0.939)\end{array}$ & 0.001 & & \\
\hline ALT (U/L) & $18.00(12.00-34.00)$ & $16.00(12.00-30.50)$ & $\begin{array}{l}23.00(16.00- \\
43.00)\end{array}$ & $\begin{array}{l}1.010(0.996- \\
1.025)\end{array}$ & 0.167 & & \\
\hline AST (U/L) & $24.00(19.00-33.00)$ & $22.00(18.00-28.50)$ & $\begin{array}{l}28.00(22.00- \\
36.50)\end{array}$ & $\begin{array}{l}1.010(0.994- \\
1.027)\end{array}$ & 0.228 & & \\
\hline Total bilirubin ( $\mu \mathrm{mol} / \mathrm{L})$ & $9.05(5.55-12.38)$ & $7.70(5.30-11.40)$ & $9.60(7.20-15.40)$ & $\begin{array}{l}1.054(0.982- \\
1.130)\end{array}$ & 0.143 & & \\
\hline Direct bilirubin $(\mu \mathrm{mol} / \mathrm{L})$ & $2.60(2.00-4.03)$ & $2.50(1.95-3.60)$ & $3.60(2.40-5.65)$ & $\begin{array}{l}1.198(1.024- \\
1.401)\end{array}$ & 0.024 & & \\
\hline GGT (U/L) & $24.00(14.00-47.50)$ & $20.00(12.00-34.00)$ & $\begin{array}{l}41.00(22.00- \\
71.50)\end{array}$ & $\begin{array}{l}1.011(1.001- \\
1.022)\end{array}$ & 0.034 & $\begin{array}{l}1.011(1.002- \\
1.021)\end{array}$ & 0.022 \\
\hline Lactate dehydrogenase & $\begin{array}{l}231.50(190.75- \\
320.25)\end{array}$ & $\begin{array}{l}211.00(183.50- \\
269.50)\end{array}$ & $\begin{array}{l}291.00(239.50- \\
394.50)\end{array}$ & $\begin{array}{l}1.008(1.004- \\
1.013)\end{array}$ & 0.001 & & \\
\hline Creatinine (mmol/L) & $65.20(52.00-79.90)$ & $65.70(51.85-79.50)$ & $\begin{array}{l}63.60(52.70- \\
81.58)\end{array}$ & $\begin{array}{l}1.004(0.987- \\
1.020)\end{array}$ & 0.668 & & \\
\hline Urea nitrogen (mmol/L) & $4.20(3.40-5.35)$ & $4.10(3.30-5.30)$ & $4.55(3.53-5.50)$ & $\begin{array}{l}1.068(0.879- \\
1.298)\end{array}$ & 0.507 & & \\
\hline Creatine kinase (U/L) & $\begin{array}{l}85.00(59.25- \\
125.00)\end{array}$ & $\begin{array}{l}85.00(60.00- \\
124.50)\end{array}$ & $\begin{array}{l}97.00(51.00- \\
134.00)\end{array}$ & $\begin{array}{l}1.003(0.998- \\
1.007)\end{array}$ & 0.270 & & \\
\hline CK-MB (U/L) & $13.00(10.00-16.00)$ & $13.00(10.00-15.00)$ & $\begin{array}{l}13.00(10.00- \\
19.00)\end{array}$ & $\begin{array}{l}1.017(0.985- \\
1.050)\end{array}$ & 0.297 & & \\
\hline Prothrombin time (s) & $12.30(11.90-12.85)$ & $12.25(11.83-12.70)$ & $\begin{array}{l}12.40(12.10- \\
13.15)\end{array}$ & $\begin{array}{l}1.247(0.769- \\
2.022)\end{array}$ & 0.371 & & \\
\hline Thrombin time (s) & $15.50(14.95-16.40)$ & 15.60 (15.10-16.65) & $\begin{array}{l}15.30(14.65- \\
16.15)\end{array}$ & $\begin{array}{l}0.975(0.707- \\
1.344)\end{array}$ & 0.877 & & \\
\hline APTT (s) & $29.30(27.25-32.95)$ & $29.20(27.13-32.38)$ & $\begin{array}{l}30.30(27.80- \\
33.75)\end{array}$ & $\begin{array}{l}1.004(0.951- \\
1.060)\end{array}$ & 0.879 & & \\
\hline D-dimer (mg/L) & $0.29(0.19-0.57)$ & $0.25(0.16-0.50)$ & $0.49(0.27-1.03)$ & $\begin{array}{l}3.883(1.485- \\
10.151)\end{array}$ & 0.006 & & \\
\hline
\end{tabular}

Abbreviations: CRP C-reactive protein, WBC white blood cell count, $R B C$ red blood cell count, $A L T$ alanine aminotransferase, AST aspartate aminotransferase, GGT $\gamma^{-}$ glutamyl transpeptidase, APTT activated partial thromboplastin time

gradually decreased with the increased $\mathrm{TOH}(p=0.012)$ (Fig. 5A). There is no significant trend of CD4 $4^{+}$to $\mathrm{CD}^{+}$ ratio with the delayed hospitalization. The proportion of $\mathrm{T}$ cell was gradually decreased with the increased $\mathrm{TOH}$ $(p=0.031)$, but the proportion of B cell was gradually increased with the increased TOH ( $p=0.003)$ (Fig. 5B).

When stratified the patients by disease severity, for mild COVID-19 patients, only the NK cell count was also gradually decreased with the increased $\mathrm{TOH}(\mathrm{p}=$ 0.012) (Fig. 5C). As shown in Fig. 5E-F, for severe COVID-19 patients, both the absolute count and proportion of $\mathrm{T}$ cell were gradually decreased with the increased $\mathrm{TOH}(p=0.001$ and $<0.001$, respectively), as well as the $\mathrm{CD}^{+}$cell (both $p<0.001$ ). The count of $\mathrm{CD}^{+}{ }^{+}$cell was gradually decreased with the increased $\mathrm{TOH}(p=0.03)$ but the proportion of $\mathrm{CD}^{+}$cell did not change with the increased TOH $(p=0.966)$. Conversely, the proportion of NK cell and B cell were gradually increased with the increased $\mathrm{TOH}(p=0.007$ and 0.002 , respectively), but the counts of NK cell and $\mathrm{B}$ cell did not change with the increased $\mathrm{TOH}(p=0.861$ and 0.930 , respectively). 


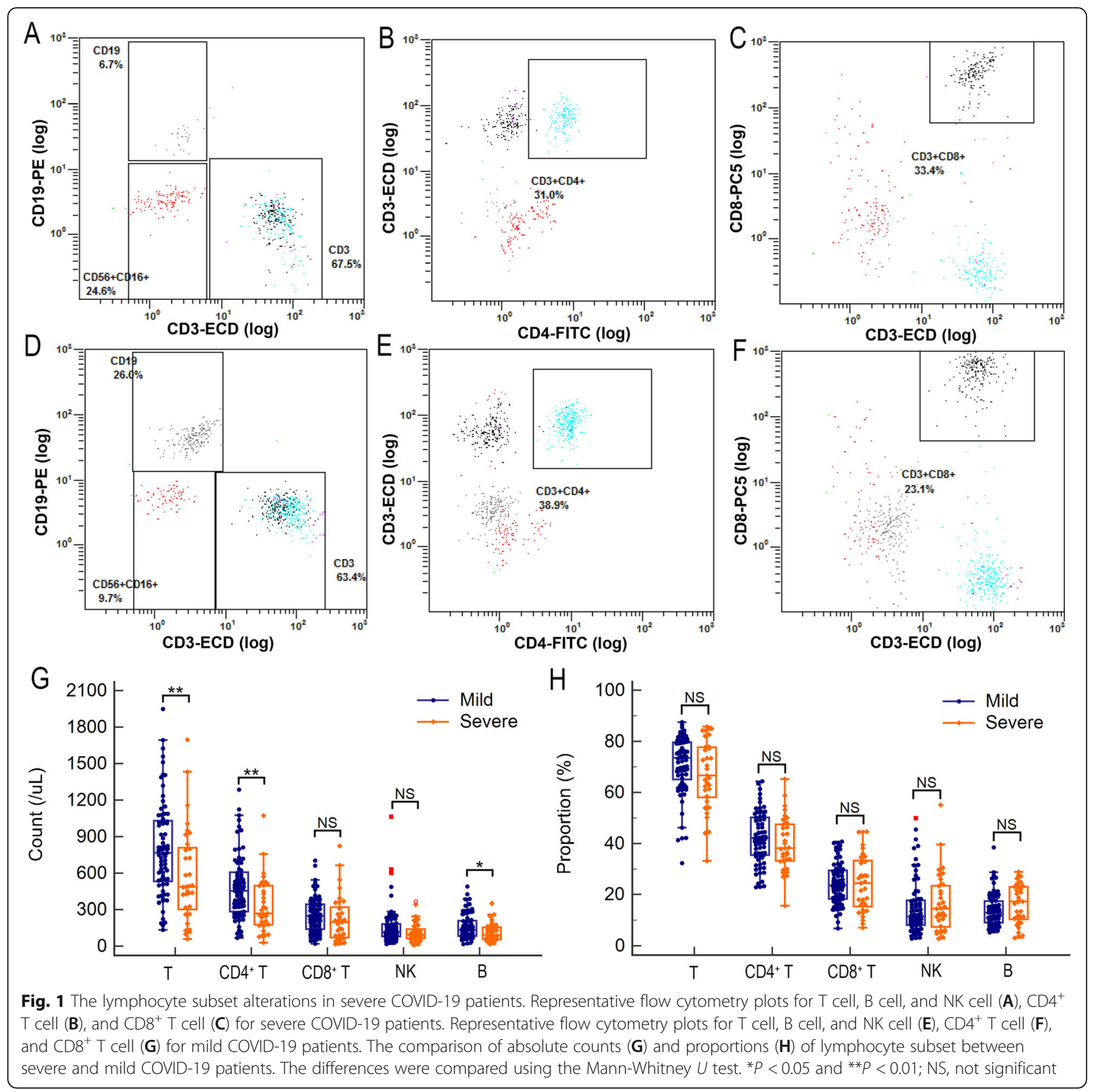

\section{Organ injury with $\mathrm{TOH}$}

As shown in Fig. 6, for all enrolled COVID-19 patients, the levels of ALT, AST, and DBil were gradually increased with increased TOH $(p=0.004,0.014$ and 0.002 , respectively), but level of albumin was gradually decreased with increased TOH $(p<0.001)$. Similar results were observed in severe patients but the AST level did not change with increased TOH $(p=0.098)$. For mild patients, only level of albumin was gradually decreased with increased TOH $(p=0.001)$. The level of TBil did not change with increased $\mathrm{TOH}$, no matter for all enrolled, mild, or severe patients. Other indicators related to injures of kidney (creatinine, BUN), coagulation (PT, APTT), cardiac muscle (CK-MB), and skeletal muscle (CK) also did not change with increased $\mathrm{TOH}$, no matter for all enrolled, mild, or severe patients (data not shown).

\section{Discussion}

COVID-19 continuously threated public health heavily, which required more bench and clinic studies to profile this disease more profoundly. The common symptoms in COVID-19 patients, in accordance with previous reports $[2,15,16]$, were fever, and followed by dry cough, 


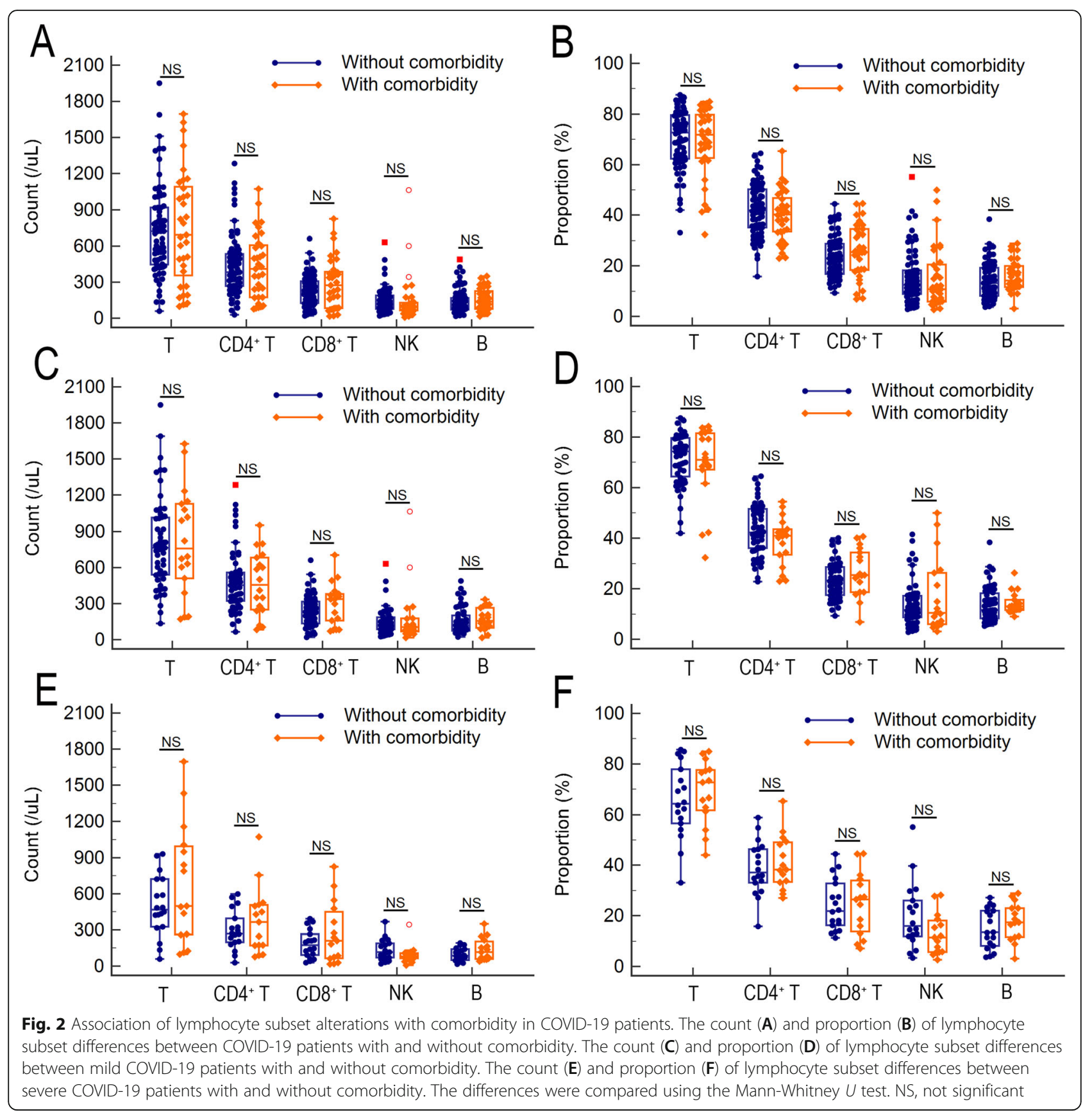

and chest tightness. Similar with studies investigated in other area $[17,18]$, the age of patients in this study was dramatically younger than those in Wuhan. Notably, the frequencies of hypertension and diabetes for COVID-19 patients in this study were also much lower than patients in Wuhan $[2,15,19]$. The underlying reason may interpret by the lower age. Present study showed that there are $11.3 \%$ patients accompanying with bacterial infection, which suggested more attention should be paid to the evaluation of bacterial infection on patients' admission. Additionally, present study found the risk of severe
COVID-19 in patients with comorbidities is much higher $(\mathrm{HR}=2.546)$ than those who without comorbidities. More importantly, present study found that the reason why patients with comorbidities were prone to severe COVID-19 were independent of their basic lymphocyte status (Fig. 2).

Complex immune dysregulation has been found in COVID-19 patients [20]. Currently, the change patterns of lymphocyte subsets were not conclusive. It is reported $[5,6]$ that a whole decline of lymphocyte subsets including $\mathrm{CD}^{+}$and $\mathrm{CD}^{+}{ }^{+} \mathrm{T}$ cells, B cells, and NK cells were 


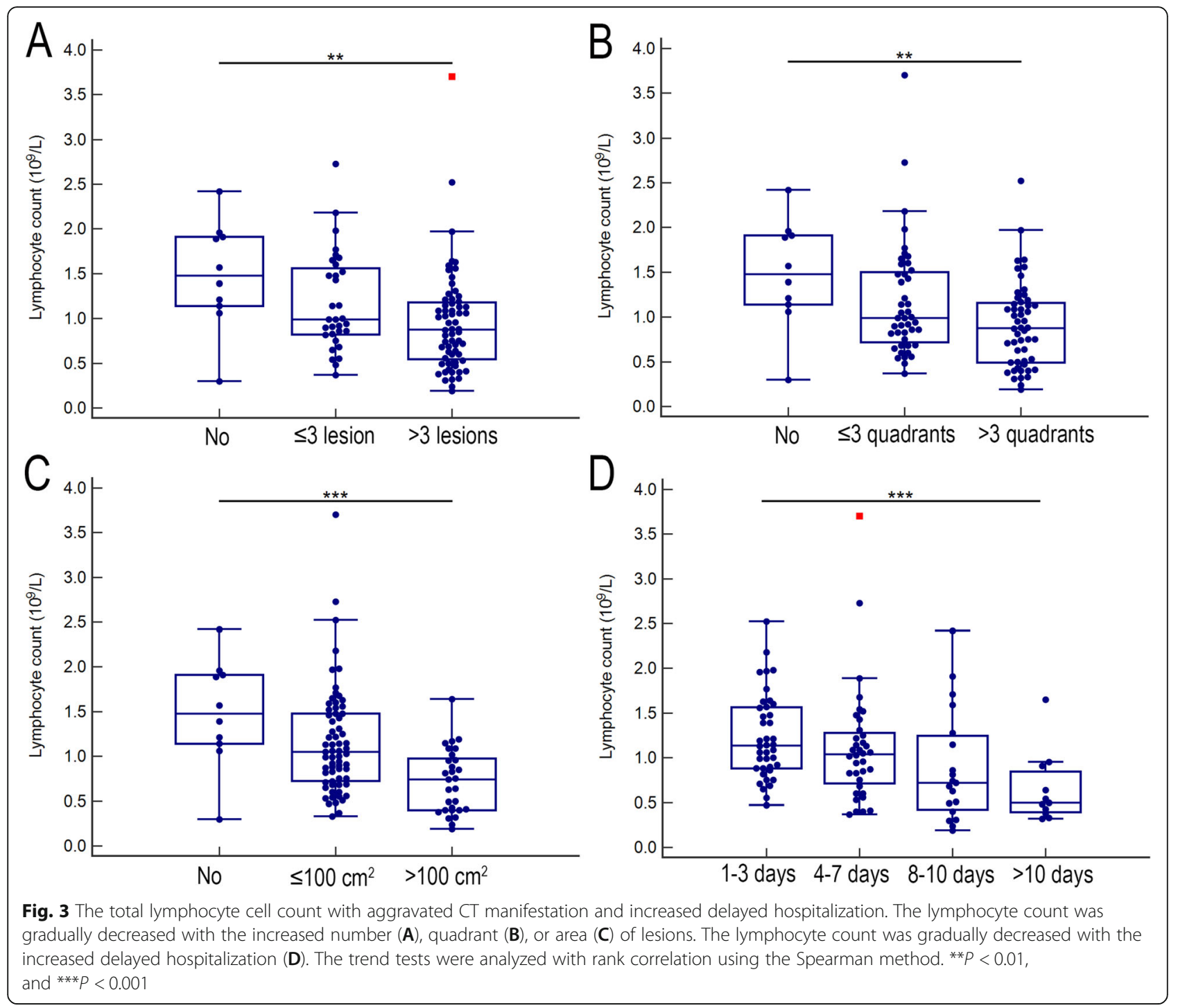

presented in severe and deceased COVID-19 patients. Liu et al. [10] suggested $\mathrm{CD} 8^{+} \mathrm{T}$ cell count was significant decreased in severe COVID-19 patients than mild patients at the time point of disease onset and 7-9 days later, but their difference in $\mathrm{CD}^{+} \mathrm{T}$ cell count was not significant at any time point. studies [7-9] also indicated decreased $\mathrm{CD}_{4}^{+}$and $\mathrm{CD} 8^{+} \mathrm{T}$ cells were correlated with disease severity of COVID-19, but there is no difference for the level of B or NK cell between severe and mild COVID-19 patients. Additionally, reports involving the change of $\mathrm{CD}^{+}{ }^{+}$to $\mathrm{CD}^{+} \mathrm{T}$ cells ratio were also inconsistent $[9,11,12]$. In this study, we found the significant percentage change of lymphocyte subsets is rare no matter in patients with severer clinical type or more extensive CT manifestation. These findings were agreement with previous studies $[4,7]$. It is noteworthy that the T cell and $\mathrm{CD}^{+}{ }^{+} \mathrm{T}$ cell but not $\mathrm{CD}^{+} \mathrm{T}$ cell were significantly decreased in severe COVID-19 patents, which suggested that $\mathrm{CD}^{+}{ }^{+} \mathrm{T}$ cell but not $\mathrm{CD}^{+} \mathrm{T}$ cell play more important role in immunity response to SARS$\mathrm{CoV}-2$ infection. Studies using SARS-CoV or MERS$\mathrm{CoV}$ infected mouse demonstrated that depletion of $\mathrm{CD}^{+} \mathrm{T}$ cells but not $\mathrm{CD} 8^{+} \mathrm{T}$ cells would lead to delayed clearance of virus and enhanced immune-mediated pneumonitis [21, 22]. Similarly, high-level $\mathrm{CD} 4^{+}$but not the $\mathrm{CD}^{+} \mathrm{T}$ cell response was also observed in SARS patients [23]. What is more, the significantly decreased $B$ cell in severe COVID-19 patents indicated that humoral immunity has been attenuated in antiviral response of SARS-CoV-2. It has reported [24-26] that T-helper type 1 (Th1), T-helper type 2 (Th2), and regulatory $\mathrm{T}$ cells were varying degrees of activated in peripheral blood from critical COVID-19 patients after stimulation with specific antigen of SARS-CoV-2. It can be speculated all the $\mathrm{CD} 4^{+} \mathrm{T}$ cell subgroups were exhaust in blood of critical COVID-19 patients for the severely damaged 


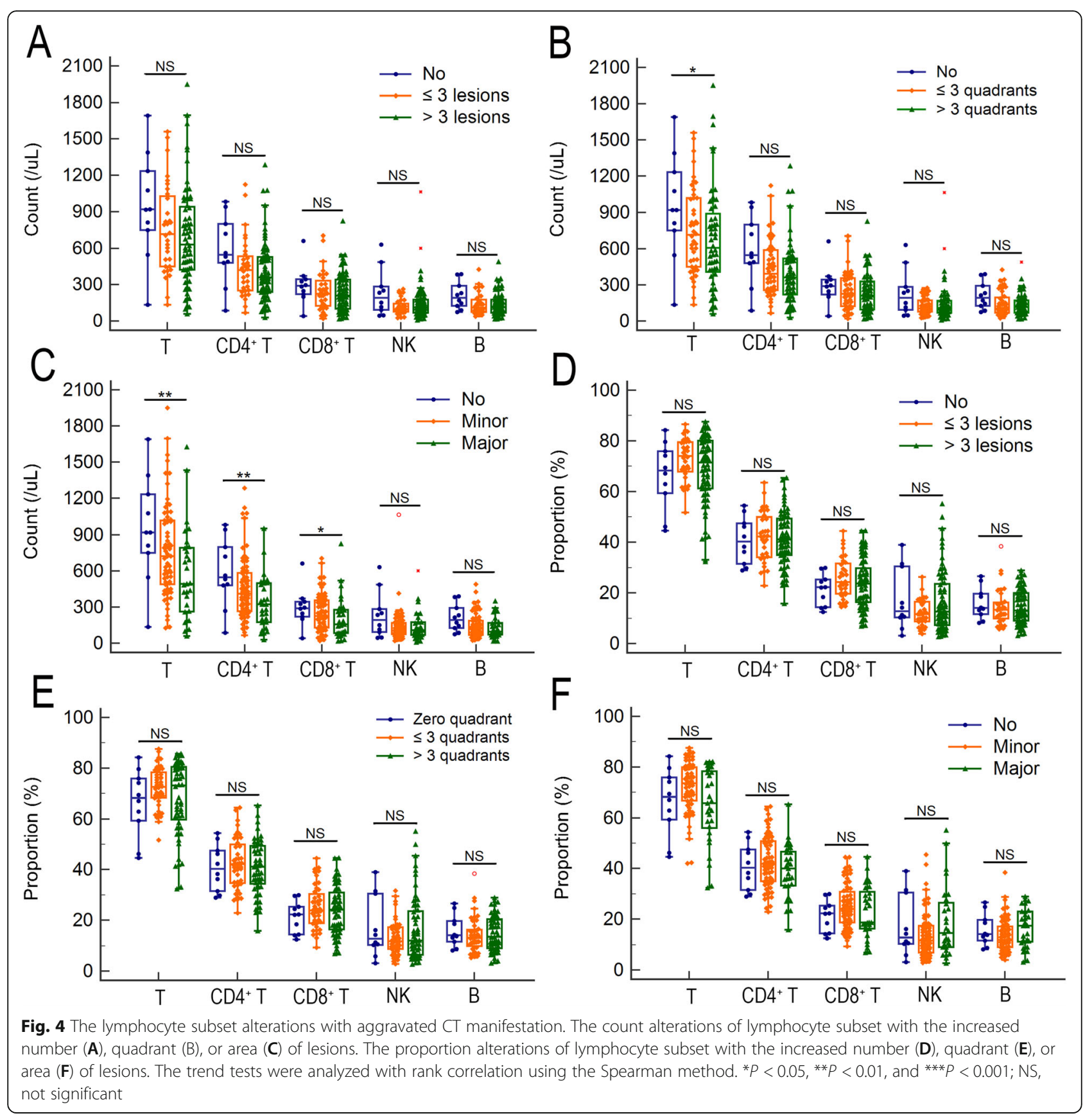

lymphoid organs and/or exudation of circulating lymphocytes into lung [9], although the alteration of $\mathrm{CD} 4^{+}$ $\mathrm{T}$ cell subsets warrants further investigation.

With regard to lymphocyte subset changes with CT manifestation, present study found that the total lymphocyte counts were gradually decreased with the increased number, infiltrated quadrants of lesions, and the area of the maximum lesion. T cell counts were gradually decreased with the increase of infiltrated quadrants of lesions and the area of the maximum lesion rather than the increased lesion number. Gradually decreased
$\mathrm{CD}^{+}$and $\mathrm{CD}^{+} \mathrm{T}$ cell counts were only observed with increased area of the maximum lesion. Those results revealed that the area of the maximum lesion was closer correlated with the count of lymphocyte subsets and was more appropriate to estimate the severity of COVID-19.

The alteration of lymphocyte subsets with the delayed hospitalization has not been reported before, present study firstly observed their correlation and found that the total lymphocyte, $\mathrm{T}$ cell, $\mathrm{CD} 4^{+}$and $\mathrm{CD}^{+} \mathrm{T}$ cell counts were gradually decreased with the the increased $\mathrm{TOH}$ for all enrolled COVID-19 patients. The same 


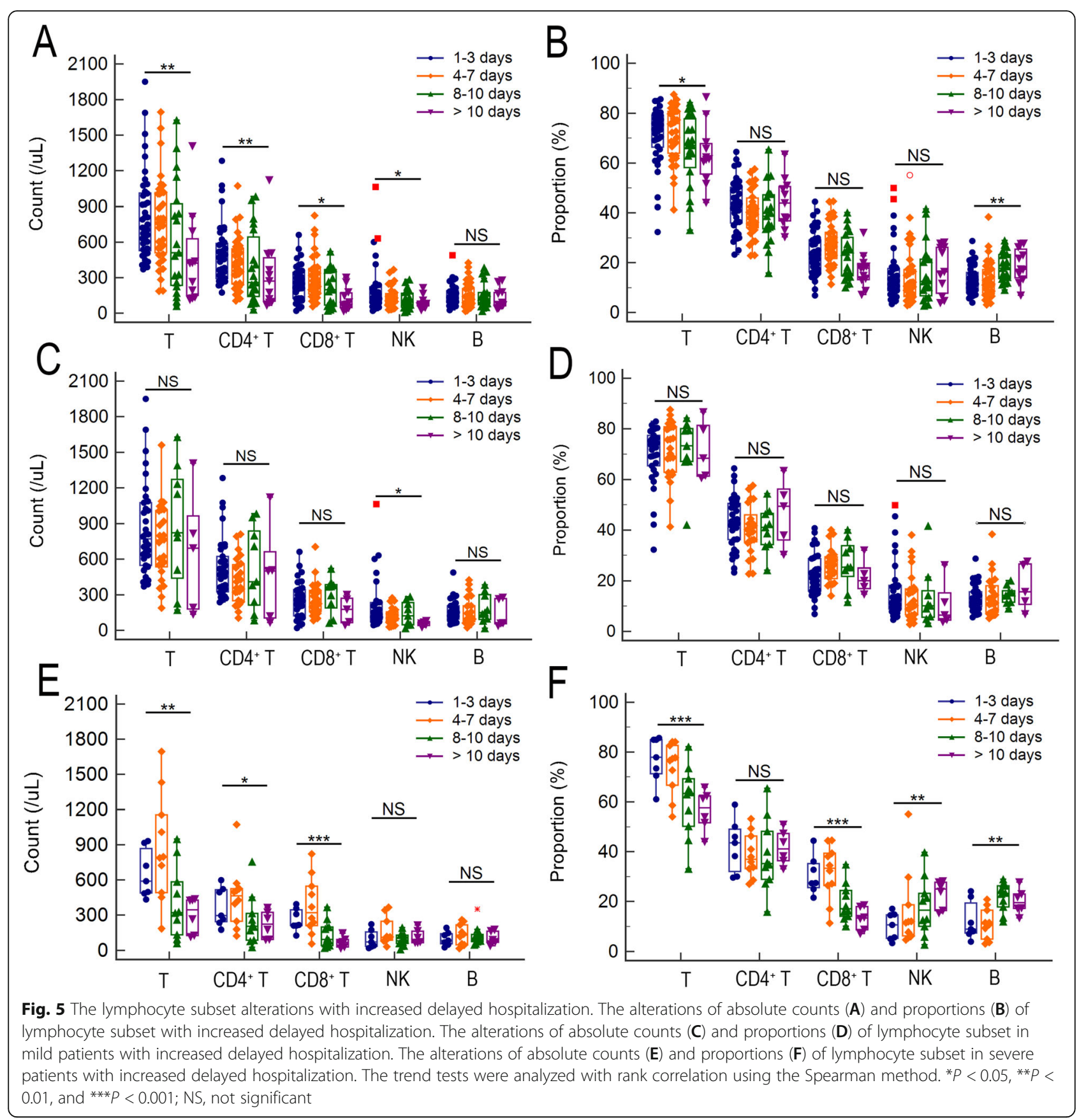

results were observed in severe patients but not observed in mild patients (Fig. 5). Those findings indicated that the lymphatic organs will continue to be damaged for severe patients if there is no intervention. Liver was a predominantly vulnerable extrapulmonary organ in patients with COVID-19, hepatic dysfunction was seen in 14$53 \%$ of cases and particularly in those with severe condition [27]. Similar with the trends of lymphocyte subsets, present study also found the level of ALT was gradually elevated with the TOH (Fig. 6), suggested that delayed hospitalization may cause more liver injure. Therefore, early hospitalization could avoid disease aggravation and the unnecessary use of scarce medical resources.

There were several limitations in this study. First, the alteration of $\mathrm{CD} 4^{+} \mathrm{T}$ cell subsets was not investigated, although $\mathrm{CD}^{+} \mathrm{T}$ cell was demonstrated to be mainstay of immunity response to severe SARS-CoV-2 infection. Second, only 3 cases with TOH more than 14 days ( $\mathrm{TOH}$ was 15,15 , and 16 days, respectively), the lymphocyte subset alterations in convalescence of COVID-19 patients were not seen in this study. More studies including patients with $\mathrm{TOH}$ more than 14 days need to 


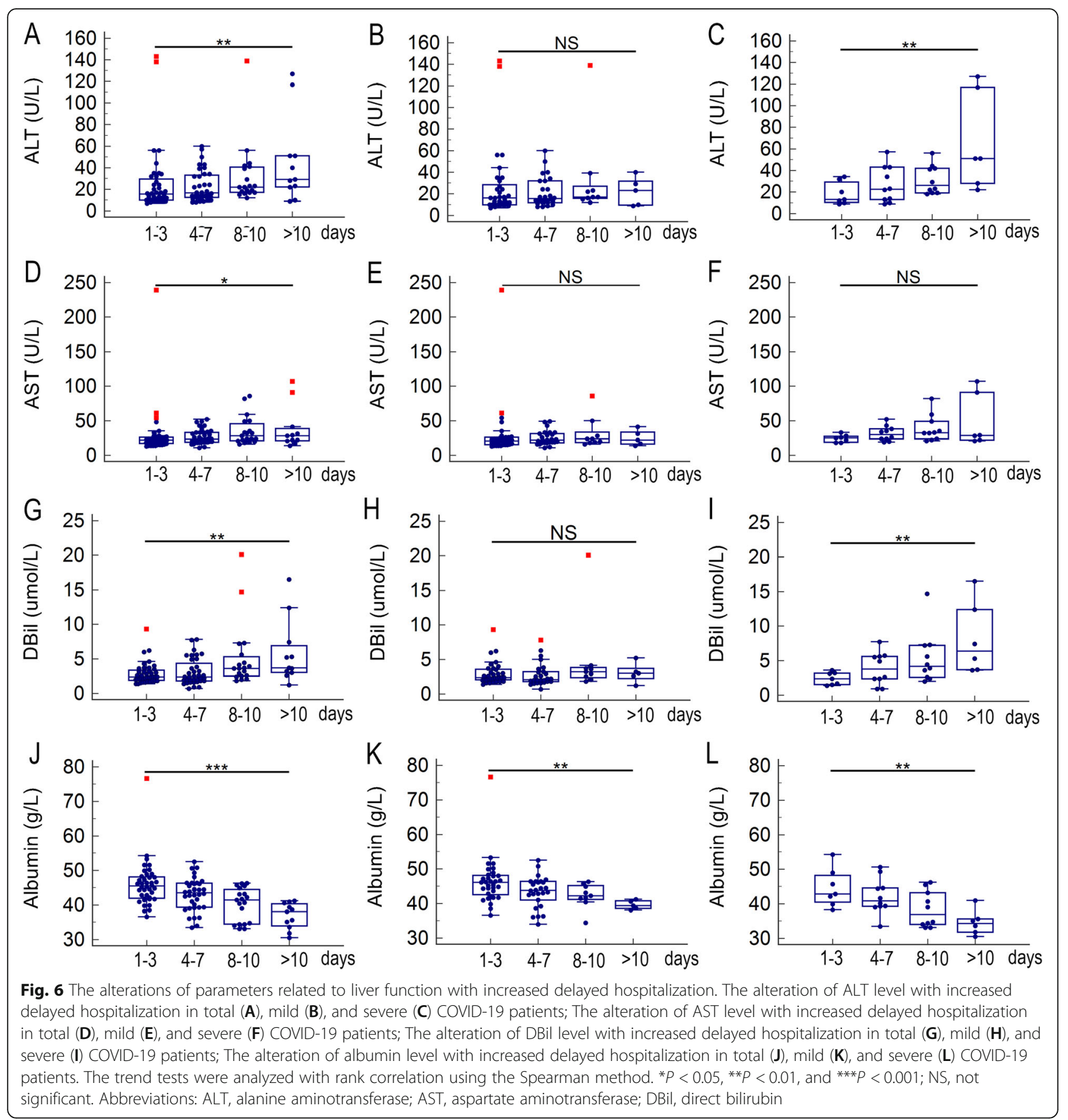

investigate to observe lymphocyte subset alterations in whole natural history of the disease.

\section{Conclusions}

Present study revealed independent predictors for severe COVID-19 and found CD4 ${ }^{+} \mathrm{T}$ cell was mainstay of immunity response to severe SARS-CoV-2 infection. T lymphocyte and its subset negatively correlated with disease severity, CT manifestation and delayed hospitalization. The counts of lymphocyte subset were changed more profound than their proportions. These findings would provide some new insights in management of COVID-19.

\section{Acknowledgements}

We would like to express our gratitude to Mei Jiang for her kind assistances in result analysis of flow cytometry.

\section{Authors' contributions}

DXW and XPW contributed equally to this work. DXW, XPW, and WFZ designed the study. JSH, QFR, and QZ enrolled the patients and collected the data. DXW and WFZ performed the statistical analysis of this work. 
Daxian Wu and WFZ analyzed and interpreted the data. DXW drafted the manuscript, XPW and WFZ provided critical revision of the manuscript. All authors approved the final version of the manuscript.

\section{Funding}

This work was funded by the National Natural Science Foundation of China (82000601), the National Science and Technology Major Project of China (2018ZX10302205), the Personnel Plan of Jiangxi Science and Technology Department (2016BCD40015), and the Project of Education Department of Jiangxi Province (GJJ170043). All sponsors of these funds have no role in the design of the study, or collection, analysis, and interpretation of data, or in writing the manuscript.

\section{Availability of data and materials}

The datasets generated and/or analyzed during the current study are available from the corresponding author on reasonable request.

\section{Declarations}

\section{Ethics approval and consent to participate}

All procedures followed were in accordance with the Ethics Committees of the First Affiliated Hospital, Nanchang University. All patients enrolled in study were over 16 years old, and written informed consent was obtained from themselves or their legal representatives.

\section{Consent for publication}

Not applicable.

\section{Competing interests}

The authors declare that they have no competing interests.

\section{Author details}

'Department of Infectious Diseases, the First Affiliated Hospital, Nanchang University, No.17 Yongwai Street, Donghu District, Nanchang 330006, Jiangxi Province, China. ${ }^{2}$ Department of Infectious Diseases, Nanfang Hospital, Southern Medical University, Guangzhou 510515, China.

Received: 30 July 2020 Accepted: 24 June 2021

Published online: 01 July 2021

\section{References}

1. Zhu N, Zhang D, Wang W, Li X, Yang B, Song J, et al. A novel coronavirus from patients with pneumonia in China, 2019. N Engl J Med. 2020;382(8): 727-33. https://doi.org/10.1056/NEJMoa2001017.

2. Huang C, Wang Y, Li X, Ren L, Zhao J, Hu Y, et al. Clinical features of patients infected with 2019 novel coronavirus in Wuhan, China. Lancet. 2020;395(10223):497-506. https://doi.org/10.1016/50140-6736(20)30183-5.

3. Xu Z, Shi L, Wang Y, Zhang J, Huang L, Zhang C, et al. Pathological findings of COVID-19 associated with acute respiratory distress syndrome. Lancet Respir Med. 2020;8(4):420-2. https://doi.org/10.1016/S2213-2600(20)30076-X.

4. Qin C, Zhou L, Hu Z, et al. Dysregulation of immune response in patients with COVID-19 in Wuhan, China. Clin Infect Dis 2020;ciaa248. doi: https:// doi.org/10.1093/cid/ciaa248.

5. Tan M, Liu Y, Zhou R, Deng X, Li F, Liang K, et al. Immunopathological characteristics of coronavirus disease 2019 cases in Guangzhou, China. Immunology. 2020;160(3):261-8. https://doi.org/10.1111/imm.13223.

6. Xu B, Fan CY, Wang AL, et al. Suppressed T cell-mediated immunity in patients with COVID-19: a clinical retrospective study in Wuhan, China. J Infect. 2020;81(1):e51-60. https://doi.org/10.1016/j.jinf.2020.04.012

7. Chen G, Wu D, Guo W, Cao Y, Huang D, Wang H, et al. Clinical and immunological features of severe and moderate coronavirus disease 2019. J Clin Invest. 2020;130(5):2620-9. https://doi.org/10.1172/JCl137244.

8. Liu Z, Long W, Tu M, Chen S, Huang Y, Wang S, et al. Lymphocyte subset $(\mathrm{CD} 4+, \mathrm{CD} 8+)$ counts reflect the severity of infection and predict the clinical outcomes in patients with COVID-19. J Inf Secur. 2020;50163-4453(20): 30182-1. https://doi.org/10.1016/j.jinf.2020.03.054.

9. Wang F, Nie J, Wang H, Zhao Q, Xiong Y, Deng L, et al. Characteristics of peripheral lymphocyte subset alteration in COVID-19 pneumonia. J Infect Dis. 2020;221(11):1762-9. https://doi.org/10.1093/infdis/jiaa150.

10. Liu J, Li S, Liu J, Liang B, Wang X, Wang H, et al. Longitudinal characteristics of lymphocyte responses and cytokine profiles in the peripheral blood of
SARS-CoV-2 infected patients. EBioMedicine. 2020;55:102763. https://doi. org/10.1016/j.ebiom.2020.102763.

11. Jiang M, Guo Y, Luo Q, Huang ZK, Zhao R, Liu SY, le AP, Li JM, Wan LG T cell subset counts in peripheral blood can be used as discriminatory biomarkers for diagnosis and severity prediction of COVID-19. J Infect Dis 2020;222(2):198-202, 2, DOI: https://doi.org/10.1093/infdis/jiaa252.

12. Chang D, Lin M, Wei L, Xie L, Zhu G, dela Cruz CS, et al. Epidemiologic and clinical characteristics of novel coronavirus infections involving 13 patients outside Wuhan, China. JAMA. 2020;323(11):1092-3. https://doi.org/10.1001/ja ma.2020.1623

13. Pan F, Ye T, Sun P, Gui S, Liang B, Li L, et al. Time course of lung changes at chest CT during recovery from coronavirus disease 2019 (COVID-19). Radiology. 2020;295(3):715-21. https://doi.org/10.1148/radiol.2020200370.

14. Metlay JP, Waterer GW, Long AC, Anzueto A, Brozek J, Crothers K, et al. Diagnosis and treatment of adults with community-acquired pneumonia. An official clinical practice guideline of the American Thoracic Society and Infectious Diseases Society of America. Am J Respir Crit Care Med. 2019; 200(7):e45-67. https://doi.org/10.1164/rccm.201908-1581ST.

15. Chen N, Zhou M, Dong X, Qu J, Gong F, Han Y, et al. Epidemiological and clinical characteristics of 99 cases of 2019 novel coronavirus pneumonia in Wuhan, China: a descriptive study. Lancet. 2020;395(10223):507-13. https:// doi.org/10.1016/S0140-6736(20)30211-7.

16. Wang D, Hu B, Hu C, Zhu F, Liu X, Zhang J, et al. Clinical characteristics of 138 hospitalized patients with 2019 novel coronavirus-infected pneumonia in Wuhan, China. JAMA. 2020;323(11):1061-9. https://doi.org/10.1001/jama.2 020.1585 .

17. Guan W, Ni Z, Hu Y, Liang WH, Ou CQ, He JX, et al. Clinical characteristics of coronavirus disease 2019 in China. N Engl J Med. 2020;382(18):1708-20. https://doi.org/10.1056/NEJMoa2002032.

18. Tian S, Hu N, Lou J, et al. Characteristics of COVID-19 infection in Beijing. J Inf Secur. 2020;80(4):401-6.

19. Du RH, Liang $L R$, Yang $C Q$, et al. Predictors of mortality for patients with COVID-19 pneumonia caused by SARS-CoV-2: a prospective cohort study. Eur Respir J. 2020;55(5):2000524. https://doi.org/10.1183/13993003.00524-202 0.

20. Giamarellos-Bourboulis E J, Netea M G, Rovina N, et al. Complex Immune Dysregulation in COVID-19 Patients with Severe Respiratory Failure. Cell Host Microbe 2020;27(6):992-1000.e3.

21. Chen J, Lau YF, Lamirande EW, Paddock CD, Bartlett JH, Zaki SR, et al. Cellular immune responses to severe acute respiratory syndrome coronavirus (SARS-CoV) infection in senescent BALB/c mice: CD4+ T cells are important in control of SARS-CoV infection. J Virol. 2010;84(3):1289-301. https://doi.org/10.1128/JVI.01281-09.

22. Zhao J, Li K, Wohlford-Lenane C, Agnihothram SS, Fett C, Zhao J, et al. Rapid generation of a mouse model for Middle East respiratory syndrome. Proc Natl Acad Sci U S A. 2014;111(13):4970-5. https://doi.org/10.1073/pna S. 1323279111

23. Li CK, Wu H, Yan H, Ma S, Wang L, Zhang M, et al. T cell responses to whole SARS coronavirus in humans. J Immunol. 2008;181 (8):5490-500. https://doi. org/10.4049/jimmunol.181.8.5490.

24. Roncati L, Nasillo V, Lusenti B, Riva G. Signals of $T(h) 2$ immune response from COVID-19 patients requiring intensive care. Ann Hematol. 2020;99(6): 1419-20. https://doi.org/10.1007/s00277-020-04066-7.

25. Weiskopf D, Schmitz K S, Raadsen M P, et al. Phenotype and kinetics of SARS-CoV-2-specific T cells in COVID-19 patients with acute respiratory distress syndrome. Sci Immunol 2020;5(48):eabd2071.

26. Zeng Z, Xu L, Xie XY, Yan HL, Xie BJ, Xu WZ, et al. Pulmonary pathology of early phase COVID-19 pneumonia in a patient with a benign lung lesion. Histopathology. 2020;77(5):823-31. https://doi.org/10.1111/his.14138.

27. Jothimani D, Venugopal R, Abedin MF, Kaliamoorthy I, Rela M. COVID-19 and liver. J Hepatol. 2020;50168-8278(20):30377-9. https://doi.org/10.1016/j. jhep.2020.06.006.

\section{Publisher's Note}

Springer Nature remains neutral with regard to jurisdictional claims in published maps and institutional affiliations. 